\title{
Evaluation of Structural Patterns and Related Alteration and Mineralization Zones by Using ASAR-ASTER Imagery in Siyahrood Area (East Azarbaijan-NW Iran)
}

\author{
Shabnam Khosroshahizadeh ${ }^{*}$, Mohsen Pourkermani1, Mahmood Almasiyan', \\ Mehran Arian'2, Ahmad Khakzad ${ }^{1}$ \\ ${ }^{1}$ Department of Geology, North Tehran Branch, Islamic Azad University, Tehran, Iran \\ ${ }^{2}$ Department of Geology, Science and Research Branch, Islamic Azad University, Tehran, Iran \\ Email: ${ }^{\text {sh.khosroshahi47@yahoo.com }}$
}

Received 7 July 2015; accepted 6 September 2015; published 9 September 2015

Copyright (C) 2015 by authors and Scientific Research Publishing Inc.

This work is licensed under the Creative Commons Attribution International License (CC BY). http://creativecommons.org/licenses/by/4.0/

(c) (i) Open Access

\section{Abstract}

The NW part of Iran belongs to the Iranian plateau that is a tectonically active region within the Alpine-Himalayan orogenic belt. The intrusion of Oligocene parts in various faces caused the alteration and mineralization such as copper, molybdenum, gold and iron in the Siyahrood area. Granitoidic rocks with component of Granodiorite to alkali have been influenced by hydrothermal fluids. Alteration zones are important features for the exploration of deposits and the ASTER sensor is able to identify the type of alteration and its alteration zoning. This method can be a useful tool for detecting potential mineralization area in East Azarbaijan-Northwest of Iran. The purpose of this study is to evaluate ASTER data for mapping altered minerals in Siyahrood area in order to detect the potential mineralized areas. In this study, false color composite, and band ratio techniques were applied on ASTER data and argillic, phyllic, Iron oxide and propylitic alteration zones were separated. ASAR image processing has been used for lineaments and faults identified by the aid of directional filter. The structural study focused on fracture zones and their characteristics including strike, length, and relationship with alteration zones. The results of this study demonstrate the usefulness of remote sensing methods and ASTER multi-spectral data for alteration, and ASAR data are useful for lineament mapping.

\section{Keywords}

Siyahrood Area, ASTER Image, Lineaments, Directional Filter, Iran

\footnotetext{
*Corresponding author.
} 


\section{Introduction}

The study of mineralization related alteration zones using remote sensing is focused on the alteration minerals and the fracture patterns of the Siyahrood area in northwest Iran. The term "Lineament" is a commonly used term in geological remote sensing. There are several definitions for linear features. The classification of lineaments and its direction and length can be easily demarcated using satellite images. The automatic lineament extraction in this paper is performed by the directional filter of ENVI software.

\subsection{Location}

The area is within zone 38S of Universal Transverse Mercator coordinate system. The upper left and lower right coordinates of the study area are 4317252N, 586593E and 4262359N, 630800E, respectively. The total area covered is $1834 \mathrm{~km}^{2}$.

\subsection{Geology Setting}

The study area is located in West-Central Alborz and lesser Caucasus province (Figure 1). Dominant structural trend in this province is NW-SE. From tectonics view, it contains deformed zone (fold and thrust belt) of Cimmerian miniplate that formed in northern active margin until late Triassic. Then it has rifted by tension in a back arc basin of Neotethyian subduction zone in the south margin of Cimmerian miniplate. Development of that rift stopped in the late Cretaceous and then, renewed in the Eocene by spreading in submarine arc basin of Neotethyian subduction zone. In other words, this hinterland is the result of a magmatic arc system spreading in the evolutional back arc basin. After that, West-Central Alborz and lesser Caucasus hinterland has formed by deformation and regional uplift from SW part of Caspian Sea to Black Sea [1]-[3]. Based on previous work on the salt and mud diapirism [4]-[15] and neotectonic regime in Iran [16]-[21], Zagros in south Iran is the most active zone [22]-[43]. Then, Alborz [44]-[83] and Central Iran [84]-[99] have been situated in the next orders.

Lithostratigraphically, the oldest rocks are of upper cretaceous age and consist of flysch type rocks and mafic to intermediate submarine volcanic rocks. They are composed of micritic limestone, sandstone, shale and mudstone. These sedimentary rocks have been folded and the calcareous layers decrease in abundance from west to east. Submarine volcanic activity is characterized by rocks of mafic to intermediate composition (andesite, basaltic andesite and pyroxene andesite) interlayered with the sedimentary sequence. The presence of Nummufallutia sp., Hetrohelicid and Globotruncana sp. in the lower part of this sedimentary unit suggests a Santonian to Maastrichtianage. Rocks of Paleocene age are poorly represented in this region. The presence of red sandstone and microconglomerate layers at the base of this sequence exhibits epeirogenic movements of Laramian phase. Gray sandstone layers with limy interbeds progressively increase up section. The sandstone is overlain by Paleocene submarine andesitic volcanic rocks and felsic tuffs; the Paleocene and upper Cretaceous rocks are unconformably overlain by Eocene strata. These Eocene rocks are $60 \mathrm{~m}$ thick with a basal conglomerate layer overlain by sandstone. The presence of Nomolite in these layers [100] indicates a Mi-Eocene age. The emplacement of Oligocene aged intrusive bodies played an important role in this region. The Qara-Dagh batholith is one of the largest intrusions of Oligocene-Miocene age covering an area of $1500 \mathrm{~km}^{2}$. Its intrusion into the Upper Cretaceous volcano-sedimentary units resulted in widespread contact metamorphism and alteration. This batholith consists of gabbro, diorite, quartz-diorite to quartz-monzonite, granodiorite, monzogranite and granite porphyry [101].

\section{Material and Methods}

\subsection{Software}

The different types of software used for this research include: ENVI v4.8, and ARCGIS v10.3 were mainly used for processing and analysis of multi-spectral and single bad images. ArcGIS v10.3 was used to georeference, digitize and capture various maps in a database. Images and maps were compared and analyzed in ArcGIS v10.3.

\subsection{RADAR (ASAR) Data}

Radar is an active form of remote sensing that provides its own source of electromagnetic energy to illuminate 


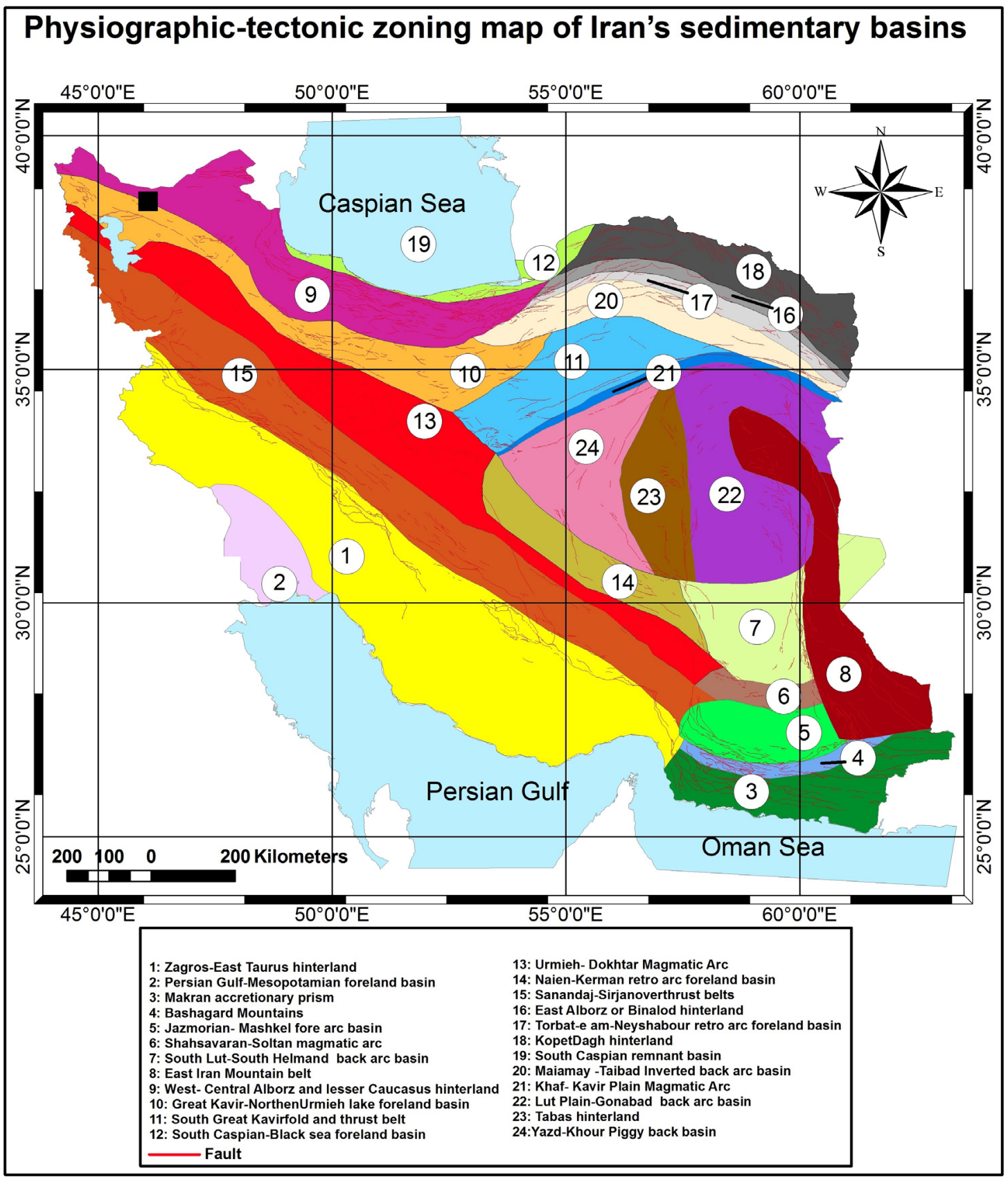

Figure 1. Physiographic-tectonic zoning map of Iran’s sedimentary basins, modified from [1]. The study area is shown in the black rectangle.

the terrain. Radar energy is measured in wavelengths of centimeters that penetrate rain and clouds which is an advantage in tropical regions. Another advantage is that radar images may be acquired at a low depression angle that causes pronounced highlights and shadows that enhance subtle topographic features. These features are commonly the expression of faults, fractures, and lithology. Radar images of vegetated regions record the vegetation surface, rather than the underlying terrain. Satellite image of the area is the main data used in this study. Considering spatial resolution of the available satellite images and the size of the study area, ASAR (Advanced Synthetic Aperture Radar), C-Band imagery (ASAR-IMP-IPN UPA), the data acquired on 06072006 is select for this study. Lineament mapping is considered as a very important issue in different disciplines to solve certain problems in the area. For example, in site selection for construction a dams, bridges, roads, etc., for mineral ex- 
ploration [102], for hot spring detection and hydrogeological research [103] the nature and the pattern of the lineaments should be known. The classification of lineaments and its direction and length can be easily demarcated using satellite image. Higher resolution images, on the other hands, may composed of three successive steps: i) the first step is the selection of input data for analysis, ii) the second step is lineament extraction by using automated lineament extraction techniques and the comparison with geological map, and iii) the last step is the evaluation of lineament map and includes, direction, length, and orientation analysis.

RADAR (ASAR') imagery was used to i) classify the various geological, ii) discriminate the lithology and structure of this area, and iii) delineate the associated zones of hydrothermal alteration a wide variety of digital images processing technique were applied.

\subsection{Directional Filters}

The automatic lineament extraction in this study is performed by the directional filter of ENVI software. The image enhancement is one of the useful tools to improve the interpretability. One of those enhancements is edge sharpening enhancement technique for enhancing the edges in an image. Directional filters (edge detection filters) are designed to enhanced linear features such as roads, streams, faults, etc. the filters can be designed to enhance features which are oriented in specific directions. Directional filter is applied to the ASAR image in N-S, E-W, NE-SW, and NW-SE directions to increase frequency and contrast in the image. There is not a commonly accepted method to prepare the final lineament map. The filtering operation will sharpen the boundary that exists between adjacent units. The main disadvantage of the filtering methods is that it cannot effectively extract lineaments in low-contrast areas where features extended parallel to the sun directions and in mountain shadows [104]. Different directional filters were applied on ASAR data. The best results were obtained for single band using the following matrix (Figures 2-6):

\begin{tabular}{cccccc}
1 & 0 & -1 & 1 & 1 & 1 \\
1 & 0 & -1 & 0 & 0 & 0 \\
1 & 0 & -1 & -1 & -1 & -1 \\
N- S Direction & \multicolumn{2}{c}{ E- W Direction } \\
& & & & & \\
1 & 1 & 0 & 0 & -1 & -1 \\
1 & 0 & -1 & 1 & 0 & -1 \\
0 & -1 & -1 & 1 & 1 & 0 \\
NE - SW Direction & NW- SE Direction
\end{tabular}

The visual inspection allowed the identification of the lineament in this region. A remotely sensed lineaments map (Figure 7) was produced depending on directional filters and edge enhancement. This map presented the lineaments detected and attributed to potential faulting in the present work. There is a general agreement between the macro-scale and the faults previously mapped by geological survey of Iran (Siyahrood 1:100,000 sheet) in Figure 8. The geological map georeferenced to the UTM zones 38S projection using WGS84 datum.

The orientations of lineaments were created by using rose diagrams (Figure 9) and trends observed in the structural map field features and the lineament map could be recognized in these diagrams, showing strongly major trend in NW-SE.

The accuracy of lineament map is computed by using ArcGIS overlay technique that determines where the lineaments and faults are matched. The output of these operation product three types of lines:

1) Non-matching lineaments: these are the lineaments that do not match to any fault line (shown as black lines in the figure and these lineaments are newest lineaments that identified by ASAR imagery).

2) Non-matching faults lines: these are the fault lines that do not match to any lineament (shown as redlines in the figure).

3) Matching lineaments and fault lines: these are the segments in yellow both lineaments and faults exist.

Evaluation of the density and orientation of the lineaments indicated that i) several fault segments are identified in the region which are absent in the fault map due the difficulty in mapping during the field studies, ii) the dominant lineament trend is NW-SE Direction (Figure 7). This trend of lineaments is overlapped by alteration zones. 


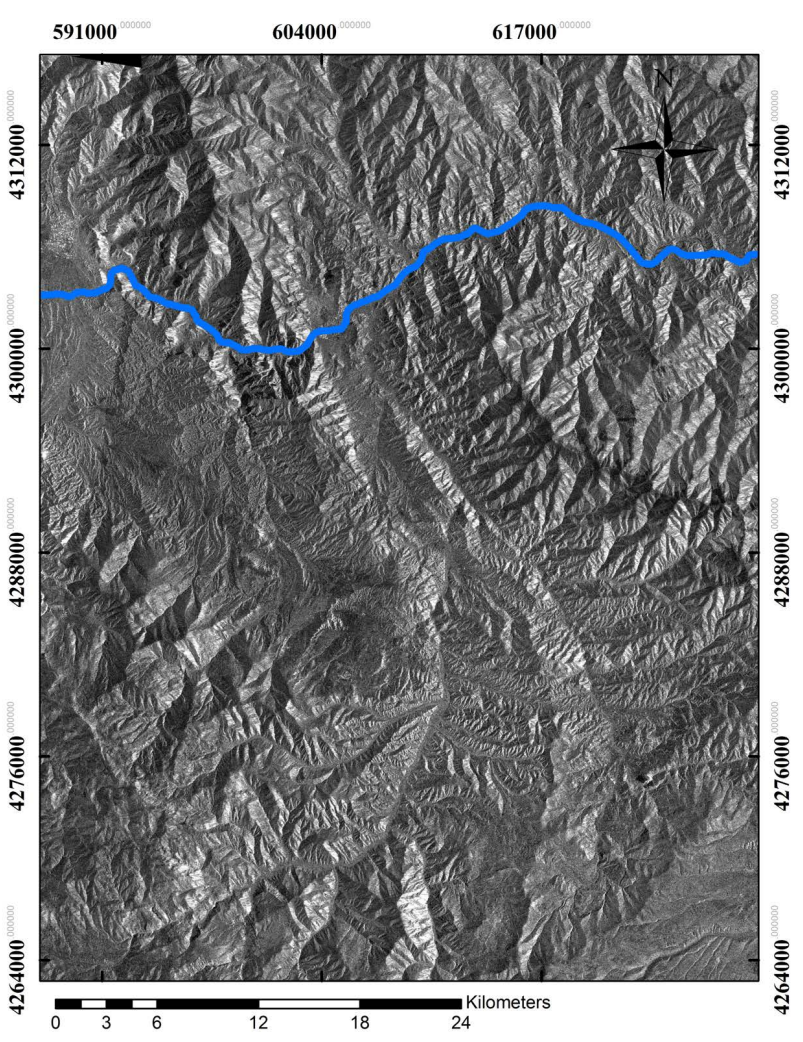

Figure 2. RADAR (ASAR) imagery of Siyahrood area.

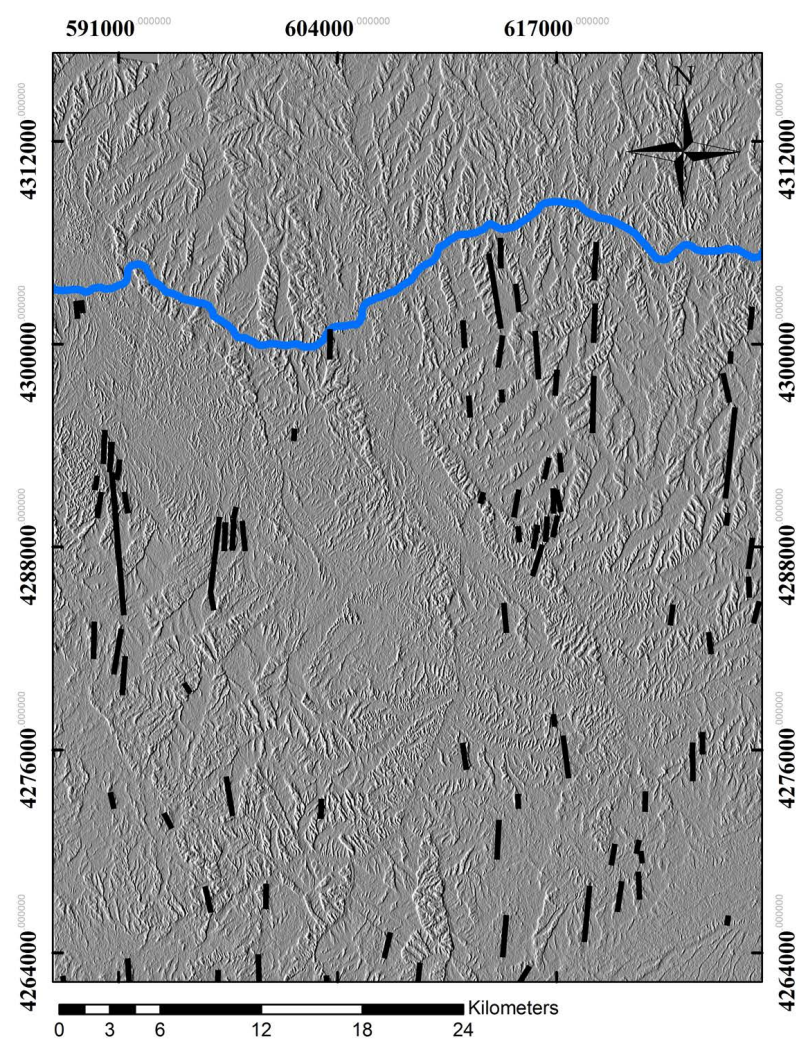

Figure 3. N-S direction and extracted lineaments. 


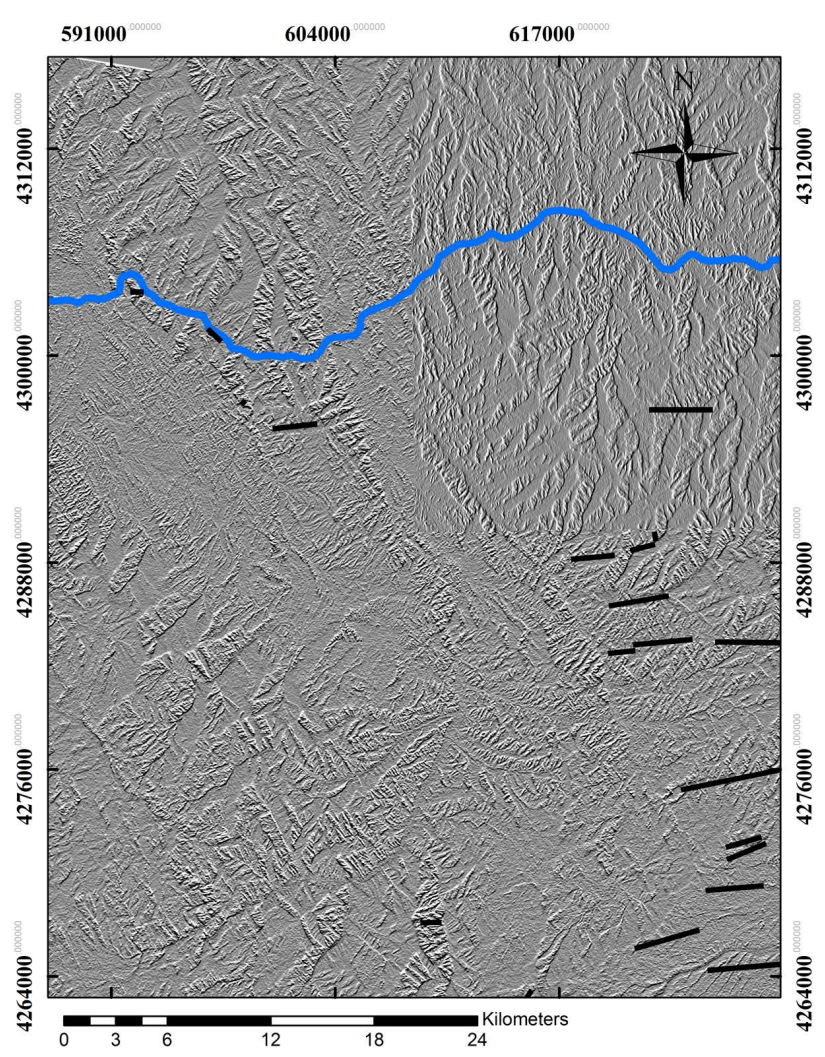

Figure 4. E-W direction and extracted lineaments.

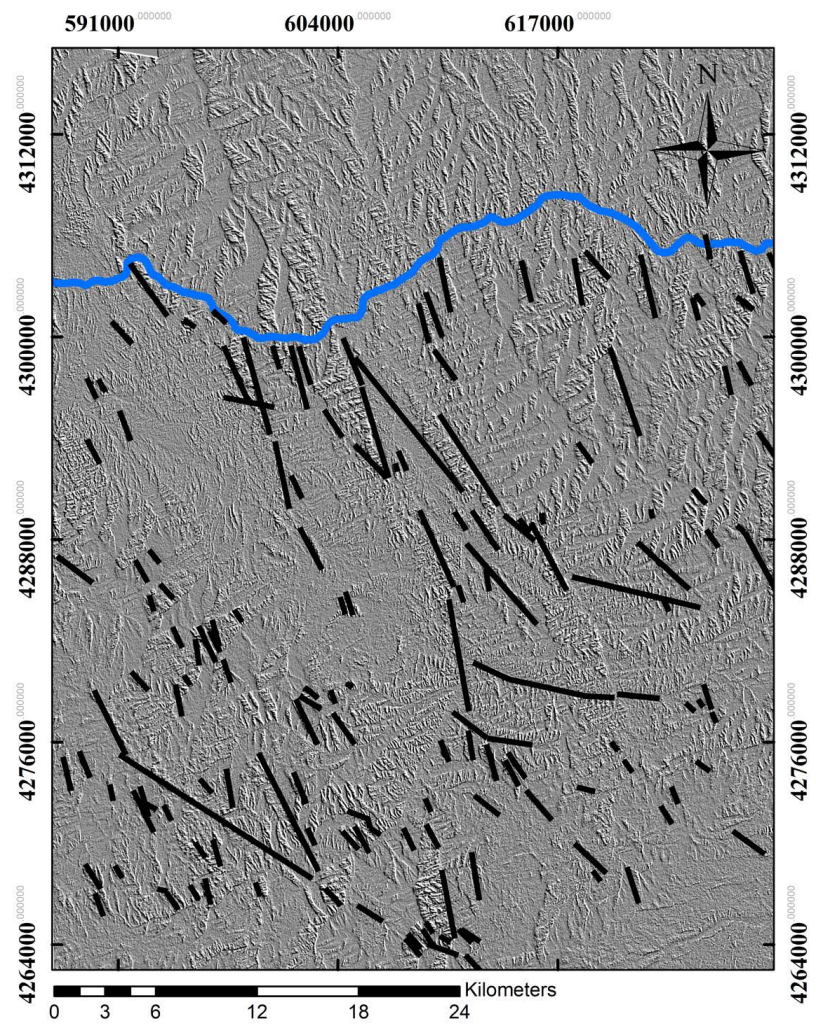

Figure 5. NW-SE direction and extracted lineaments. 


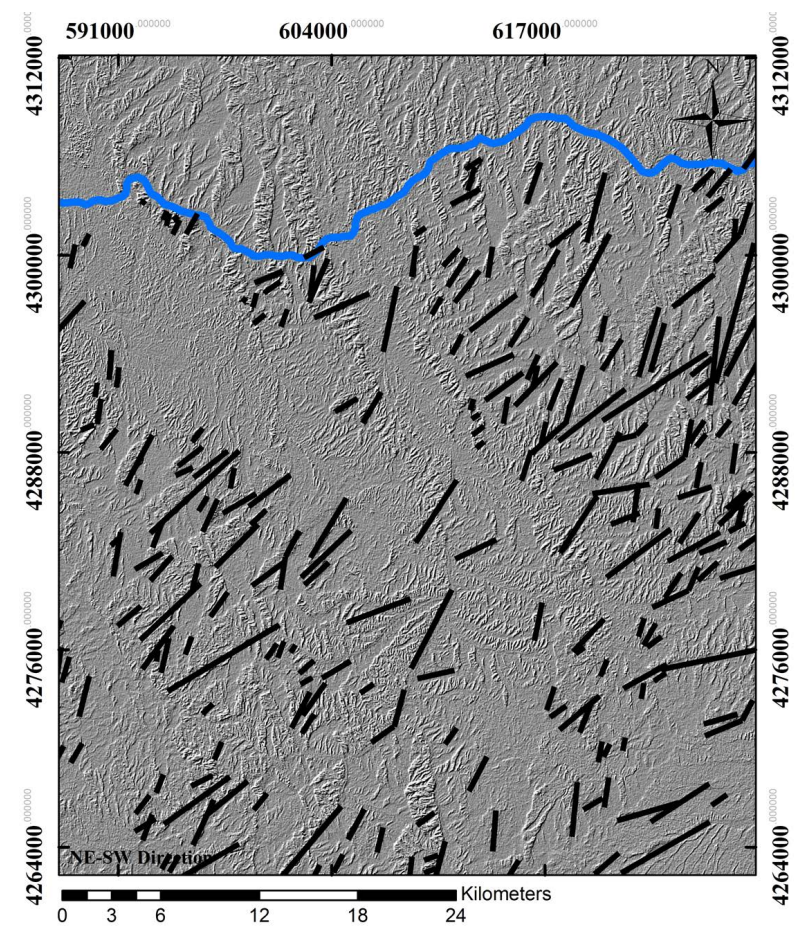

Figure 6. NE-SW direction and extracted.
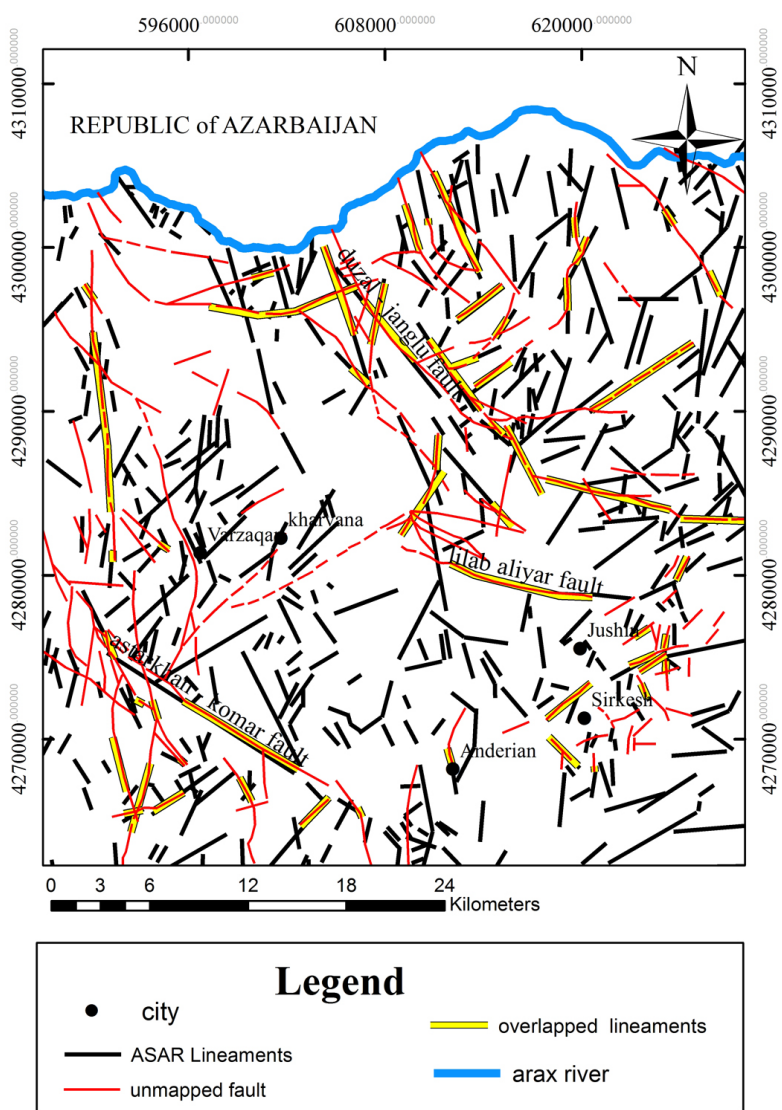

Figure 7. Lineament map generated after directional filtering operation. 


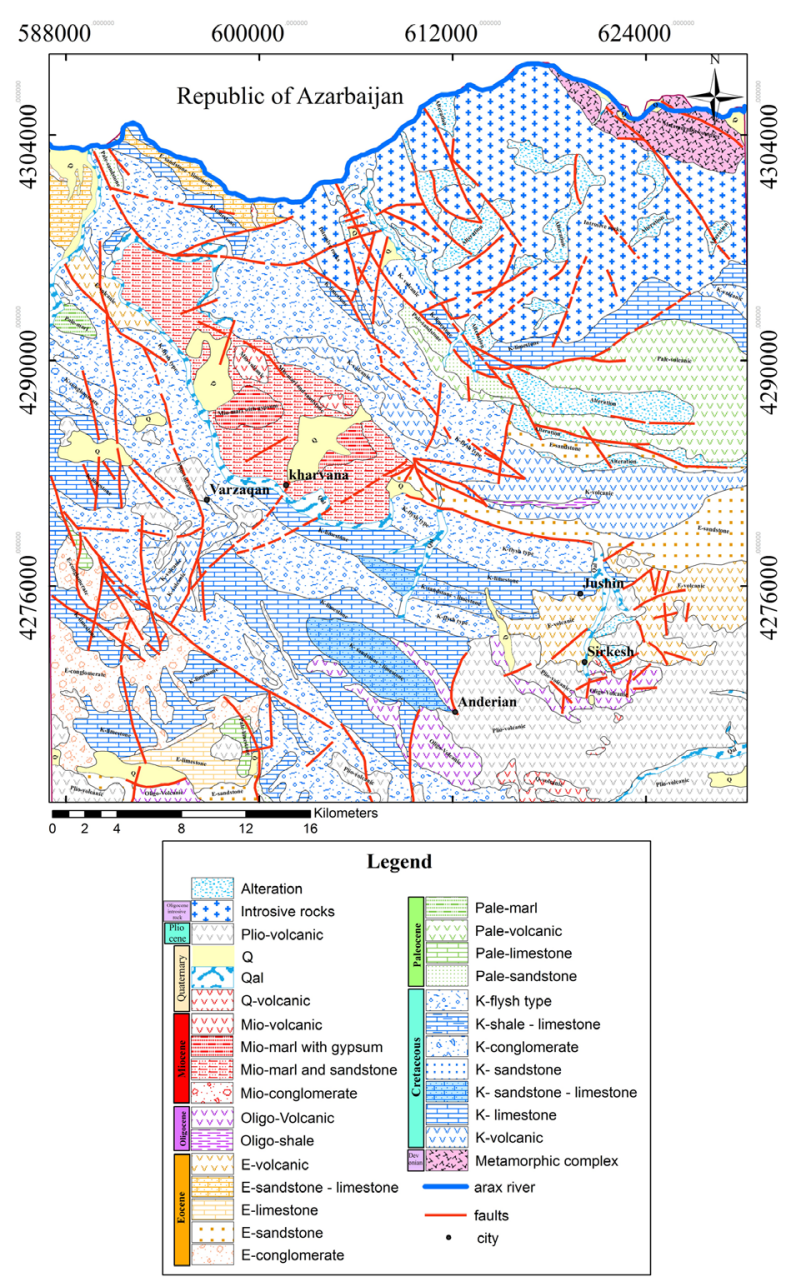

Figure 8. Map of previously verified faults by geological survey of Iran.

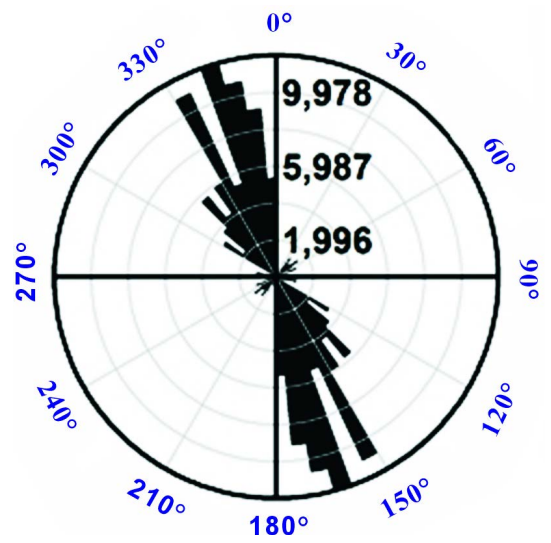

Figure 9. Dominant directions of lineaments.

\subsection{ASTER Data}

ASTER (Advanced Spaceborne Thermal Emission and Reflection Radiometer) is an advanced multi-spectral satellite imaging system, which was launched on board of the TERRA spacecraft in December, 1999 by NASA and METI (Japan Ministry of Economic Trade and Industry). It measures reflected radiation in VNIR (0.52 and 
$0.86 \mu \mathrm{m}$ ), SWIR (11.6 to $2.43 \mu \mathrm{m}$ ), and emitted radiation in TIR wavelength region (8.125 to $11.65 \mu \mathrm{m}$ ) with 3 , 6,5 bands and $15 \mathrm{~m}, 30 \mathrm{~m}, 90 \mathrm{~m}$ resolution, respectively. The swath-width is $60 \mathrm{~km}$, but ASTER's pointing capability extends the total cross-track viewing capability to $232 \mathrm{~km}$ [105]. Since 2000, ASTER has been successfully used for hydrothermal alteration mineral mapping in well-exposed areas.

Based on the spectral properties of typical alteration mineral and geological background, two image processing techniques were selected to identify different alteration minerals, including Band ratio and color composite. Hydrothermal ore deposits are created by the activity of fertile fluids that are rich in metals. Porphyry copper type deposits ( $\mathrm{Cu} \pm \mathrm{Au} \pm \mathrm{Mo}$ ), epithermal auriferous vein type deposits (Au-Ag), subepithermlpolymetallic vein type deposits (Zn-Cu-Pb-Ag $\pm \mathrm{Au}$ ), and skarn type deposits (Zn-Pb), are spatial situations from the multiphase porphyry stock [106].

Remote sensing used in mineral exploration of hydrothermal ore deposits often use the spectral features of the alteration minerals at wavelength of 2.0 to $2.5 \mu \mathrm{m}$ to find alteration zones and identify alteration minerals. ASTER has five bands in this region and is able to identify not only the presence of alteration zones. Alunite and kaolinite, which are alteration minerals present in advanced argillic alteration, have absorptions at $2.16 \mu \mathrm{m}$ and $2.2 \mu \mathrm{m}$ that are created by the aluminum hydroxyl (Al-OH) bond. Sericite, which is a typical alteration mineral in phyllic alteration, has an absorption at $2.2 \mu \mathrm{m}$ that is also created by the Al-OH bond. Chlorite, epidote and calcite, which are present in propylitic alteration, have an absorption at $2.35 \mu \mathrm{m}$ that is created by the magnesium hydroxyl $(\mathrm{Mg}-\mathrm{OH})$ bond and the carbonic $\left(\mathrm{CO}_{3}\right)$ bond. These alteration minerals can be identified by ASTER's five spectral bands in wavelength of 2.0 to $2.5 \mu \mathrm{m}$, but the potassic alteration that is located at the center of the alteration zoning of the porphyry copper deposit could not be identified from the spectral pattern of the visible near infrared (VNIR) to SWIR because K feldspar and biotite does not have a characteristic absorption in this wavelength region.

\subsection{Color Composites}

The human eye is capable of discriminating about 30 grey levels in the black to white range [107] but much more sensitive color differences to recognize color patterns. Therefore, different false color combinations of ASTER multi-spectral images were used to identify lithologic units, and hydrothermal alteration zones. SWIR false color images created by applying ASTER band 4, 6, and 8 to red (R), green (G), and blue (B) (R:G:B = 4:6:8) are useful for identification of alteration. In this SWIR false color image, advanced argillic alteration (alunite, kaolinite) and phyllic alteration (sericite, smectite) are indicated in red to pink, propylitic alteration (chlorite, epidote) is indicated in pale green and calcareous units are indicated in yellow. Advanced argillic and phyllic alteration both have absorption at band 6, low reflectance at band 8, high reflectance at band 4 and appear as red to pink in the $\mathrm{R}: \mathrm{G}: \mathrm{B}=4: 6: 8$ image. Propylite alteration has absorption at band 8 caused by $\mathrm{Mg}-\mathrm{OH}$, broad absorption at band 4 caused by iron in chlorite or epidote, no absorption at band 6 and appear as pale green in the SWIR false color image. Calcite has absorption at band 8 caused by $\mathrm{CO}_{3}$, but does not have absorption at band 4 because calcite lacks iron and no absorption at band 6 and appears as yellow in the SWIR false color image (Figure 10).

VNIR false color and natural color images provide more detailed surface information compared to the $30 \mathrm{~m}$ resolution SWIR false color image and are useful as map images for field surveys.

Mafic-to-ulteramafic and granitic units are important targets for mineral exploration because they are potential geological units to host or accompany mineralization. In TIR region, band 10, 11, and 12 contain spectral emissivity and temperature information. Visual interpretation of the ASTER TIR false color images generated by assigning band 14, band 12, and band 10 (R:G:B = 14:12:10) using to identify mafic-to-ulteramafic units and quartz-rich felsic units (Figure 11).

ASTER band ratio technique has been widely used in geological mapping by different authors [108] [109]. In this study we use these ratios to identify as following:

Alunite and kaolinite are the main alteration minerals present in the advanced argillic alteration. In the SWIR region, alunite and kaolinite both have absorption at ASTER bands 5 and 6 . Alunite and kaolinite identification can be enhanced by band ratio of b4/b6 (Figure 12).

Sericite is the main alteration mineral present in the phyllic alteration. Sericite has a single deep absorption at ASTER band 6. Sericite can be enhanced by band ratio b5/b6 (Figure 13).

Chlorite and epidote are the main alteration minerals present in the propylitic alteration and have absorption at ASTER band 8. Chlorite, epidote and calcite can be enhanced by band ratio b5/b8 (Figure 14). 


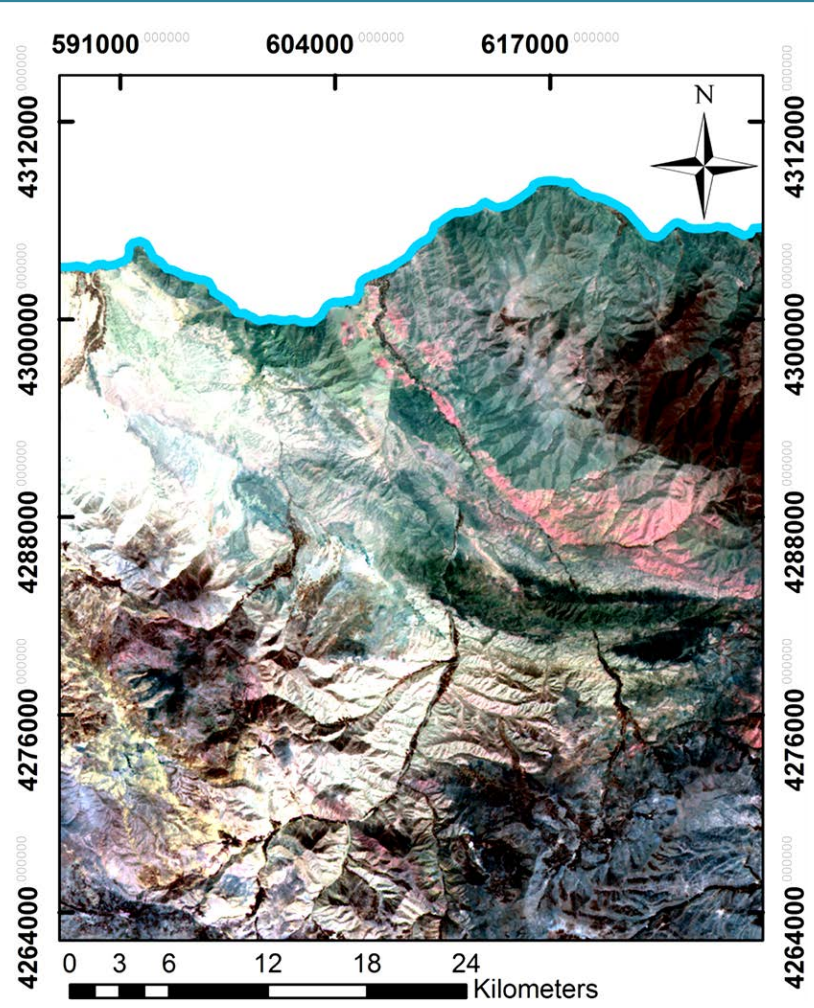

Figure 10. In the SWIR false color image, advanced argillic (alunite, kaolinite) alteration and phyllic alteration (sericite, smectite) appear as pink, propylitic alteration (chlorite, epidote) appears as green and calcareous units appear as yellow as distinct features identifiable without error.

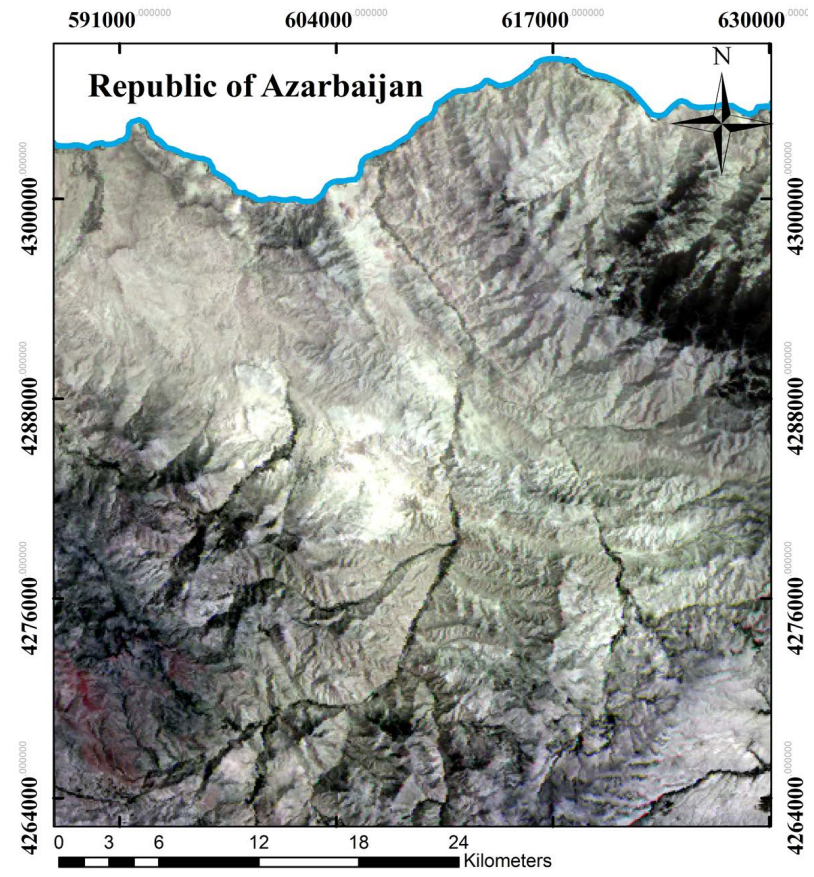

Figure 11. Color copmpsite in TIR region (R: 14, G: 12, B: 10) to identify mafic-to-ulteramafic units and quartz rich felsic units. 


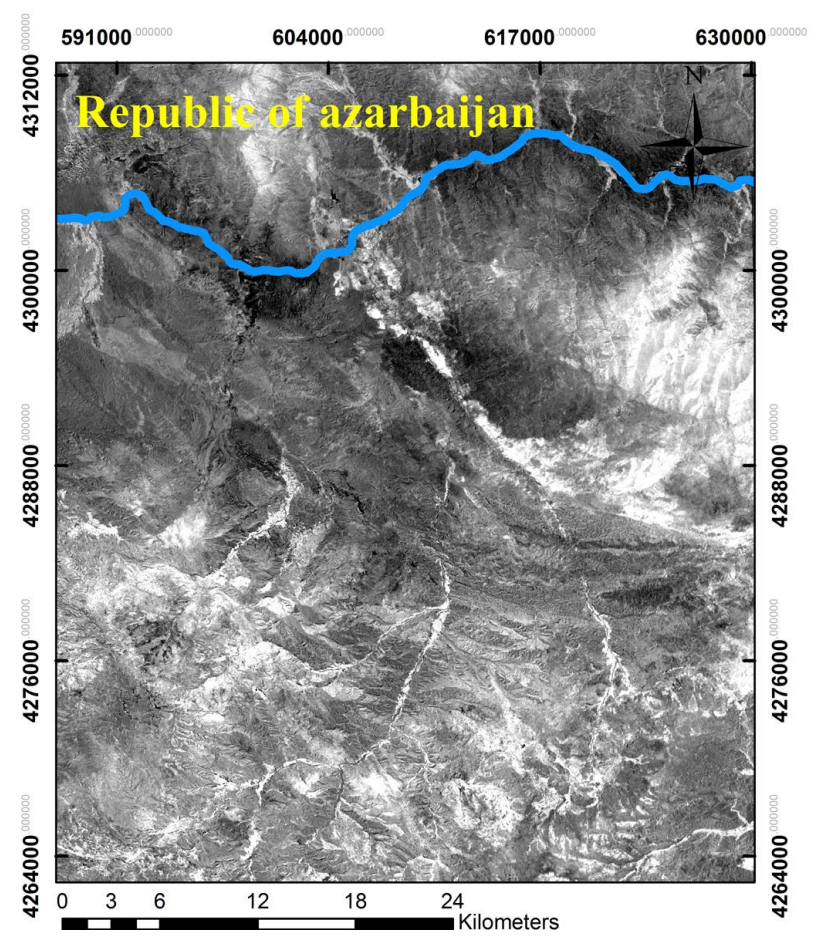

Figure 12. Alunite and kaolinite identification enhanced by band ratio of b4/b6.

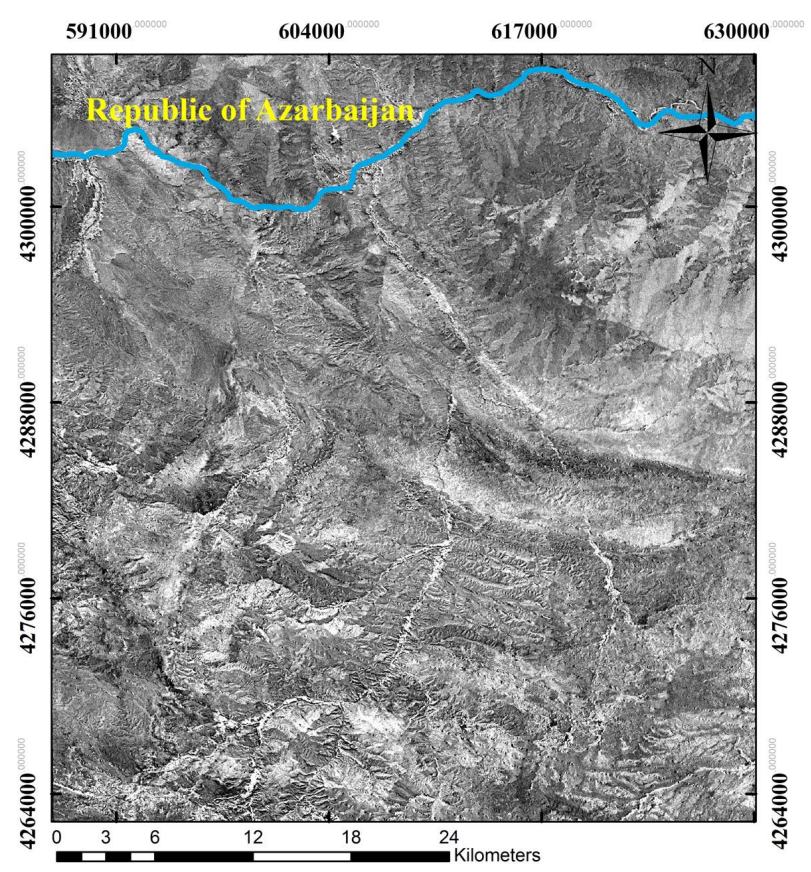

Figure 13. Sericite enhanced by band ratio B5/B6.

Advanced argillic alteration, phyllic alteration, propylitic alteration and calcite can be identified by the color composite image of band ratios by applying advanced argillic alteration to red, phyllic alteration to green and propylitic alteration to blue (R:G:B = 4/6:5/6:5/8) (Figure 15).

Spectral emissivity features due to the lattice vibration of Si-O in the thermal infrared (TIR) region are useful for identifying silicate rocks and minerals. A difference in thermal properties has been used to identify geological 


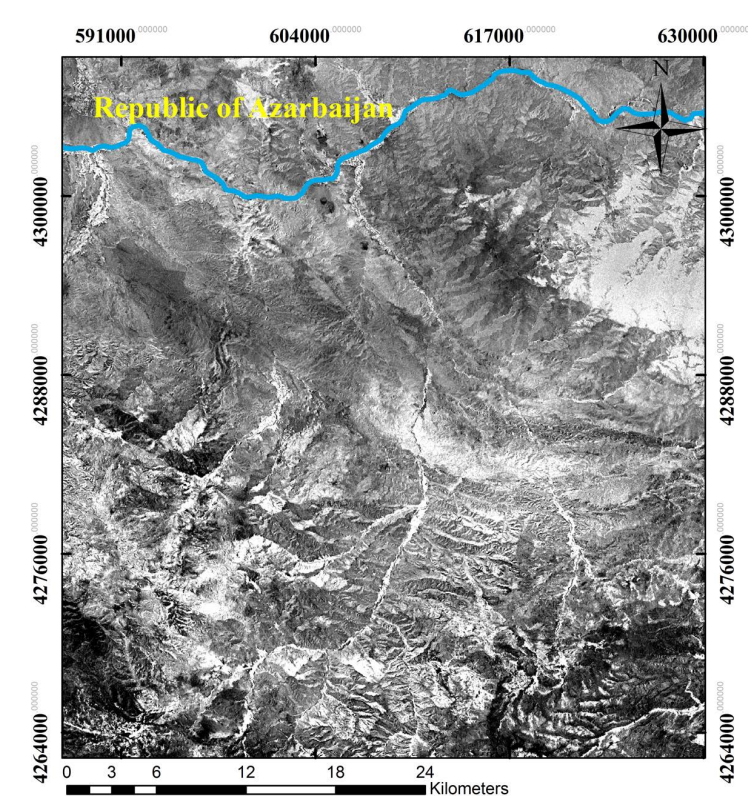

Figure 14. Chlorite, epidote and calcite enhanced by band ratio b5/b8.

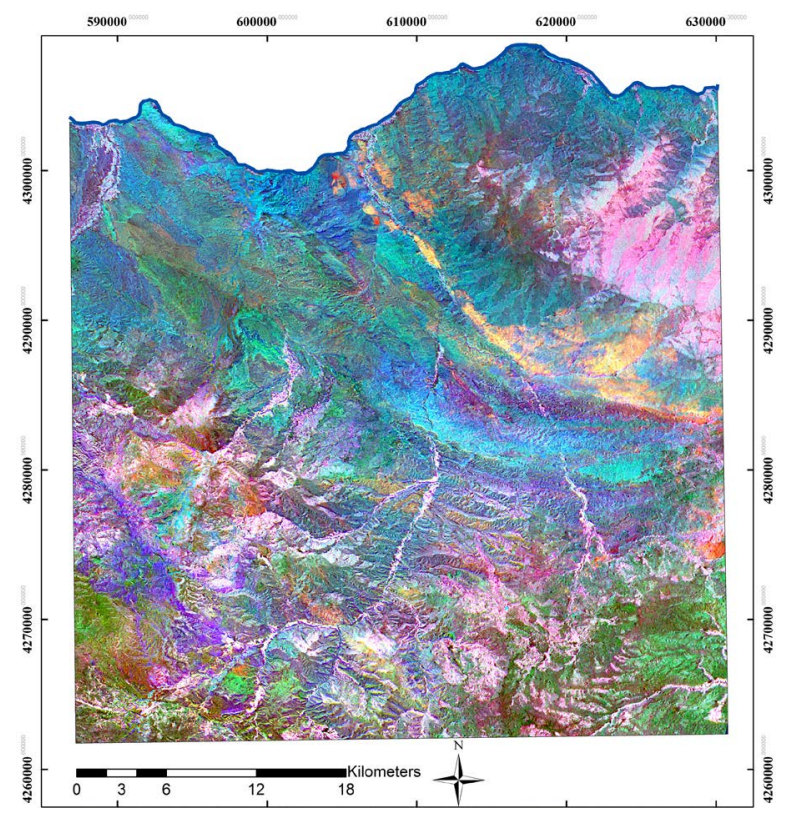

Figure 15. Color composite image of band ratios by applying advanced argillic alteration to red, phyllic alteration to green and propylitic alteration to blue (R:G:B = 4/6:5/6:5/8).

units [110]-[113] and the thermal inertia method has been used to distinguish different rock types [114]-[116]. [117] use ASTER band ratio (b5 + b7)/b6 for mapping the distribution of granitoids and gneisses in Mountain Pass, California (Figure 16).

B4/b2 and mineralogic indices proposed by Ninomiya were designed to map the distribution of Fe-Oxide and alteration zones (Figure 17).

[118] used ASTER band ratio (b13/b12) for mapping quartz (Figure 18) and b2/b1 for ferric-iron oxide minerals in hydrothermal alteration zone associated with Au-Cu mineralization in the RekoDiq, Pakistan (Figure 19). 


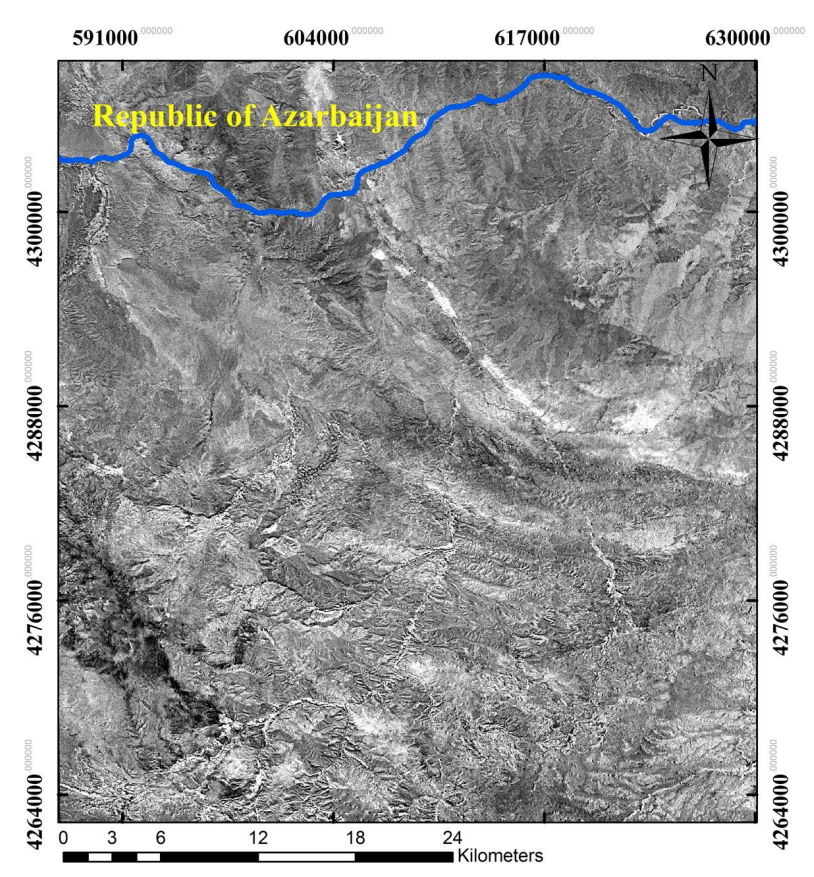

Figure 16. Band ratio (b5 + b7)/b6 for mapping the distribution of granitoids and gneisses.

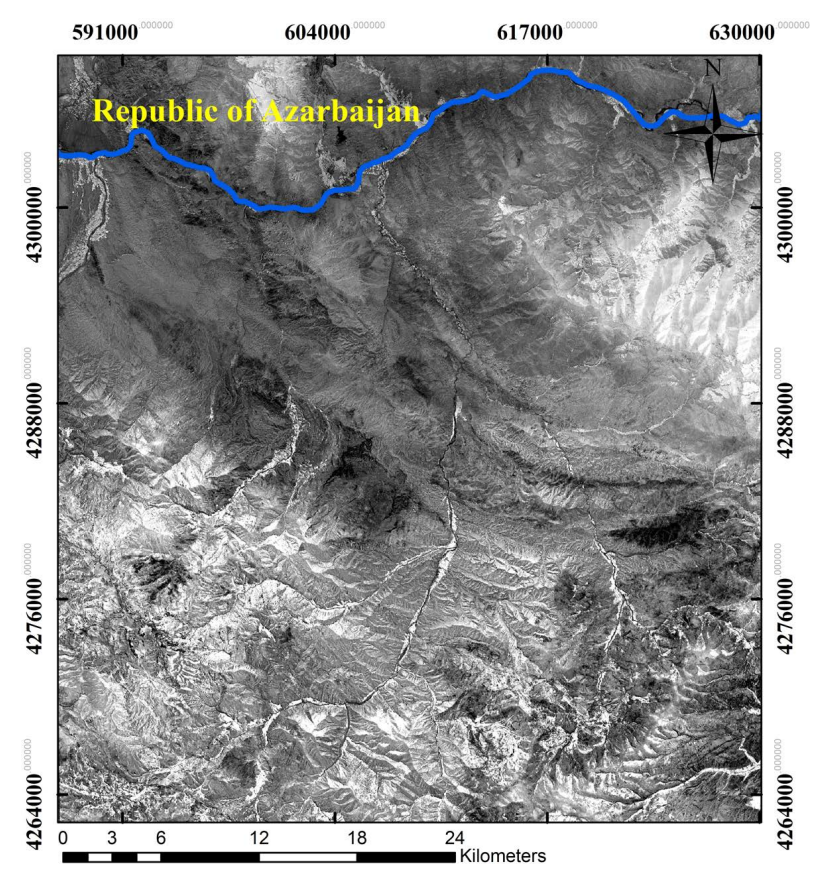

Figure 17. Band ratio of B4/b2 to map the distribution of Feoxide.

[119] identified ASTER and band ratio (B2 + B4/B3, B5 + B6/B7, B7 + B9/B8) as a promising tool for mapping the ophiolitic and granitic rocks in the central eastern desert of Egypt. ASTER data has been also used for mapping alteration minerals in different rock types for mineral exploration (Figure 20).

Color composite ratio images are produced by combining three ratio images in blue, green, and red. According to the Figure 21 band ratios 3/5, 3/1, and 5/7 in red, green, and blue, respectively. The orange and yellow hues delineate the outer and inner areas of altered rocks in a pattern similar to that of the density sliced ratio images. 


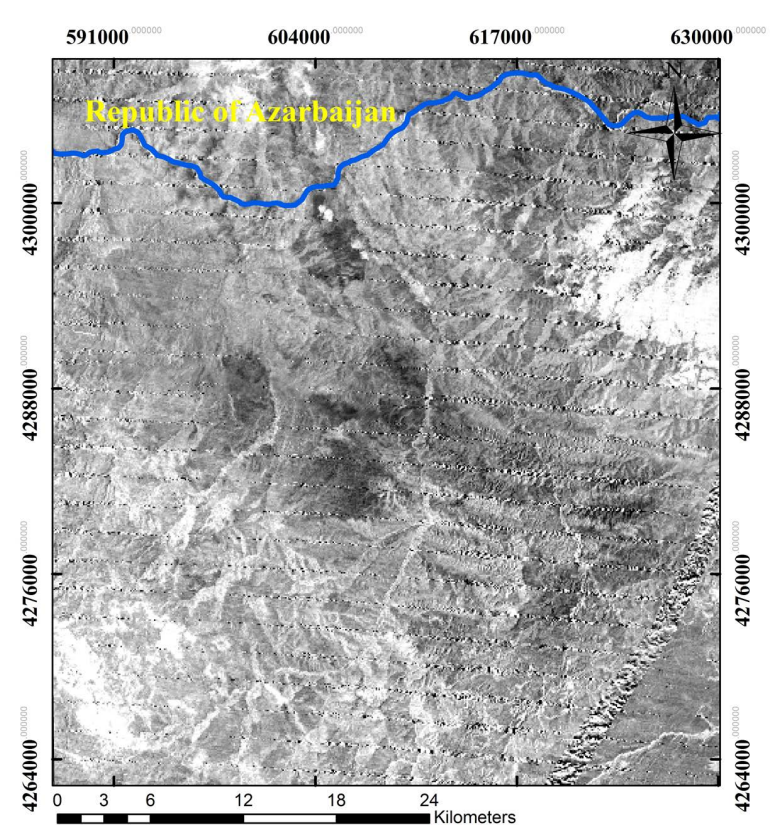

Figure 18. Band ratio (b13/b12) for mapping quartz.

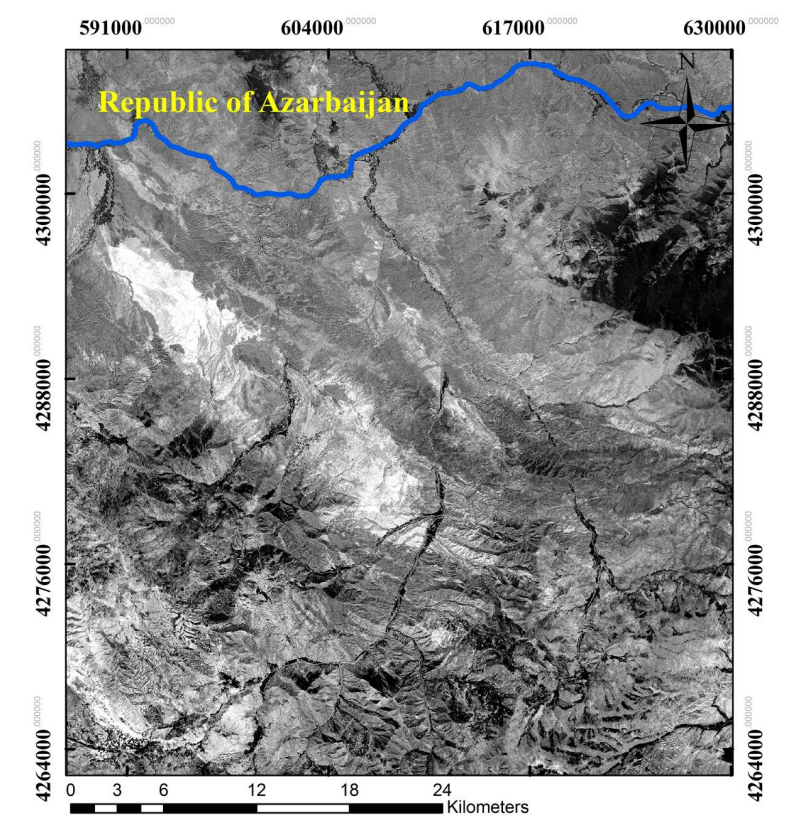

Figure 19. Band ratio of b2/b1 for ferric-iron oxide minerals.

An advantage of the color ratio image is that it combines the distribution patterns of both iron minerals and hydrothermal clays. A disadvantage is that the color patterns are not as distinct as in the individual density-sliced images.

[119] has used band ratio composite of (B2/B1, B4/B9, B3/B2) in RGB respectively for mapping alteration zones. In the Figure 22 showing image of compound band ratio of RGB (B2/B1, B4/B9, B3/B2) that yellow color represents the presence of hydrothermal alteration in this region.

\section{Results and Discussion}

The spectral properties of hydrothermally altered rocks provide a basis for mapping the alteration minerals using 


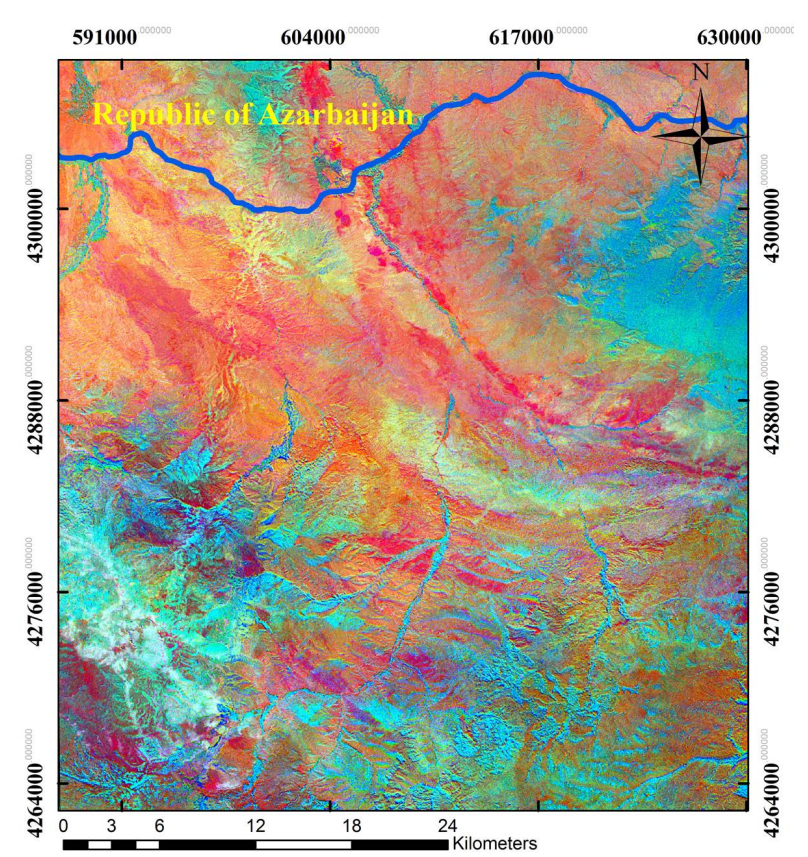

Figure 20. Band ratio (b2 + b4/b3, b5 + b6/b7, b7 + b9/b8) as a promising tool for mapping the ophiolitic and granitic rocks.

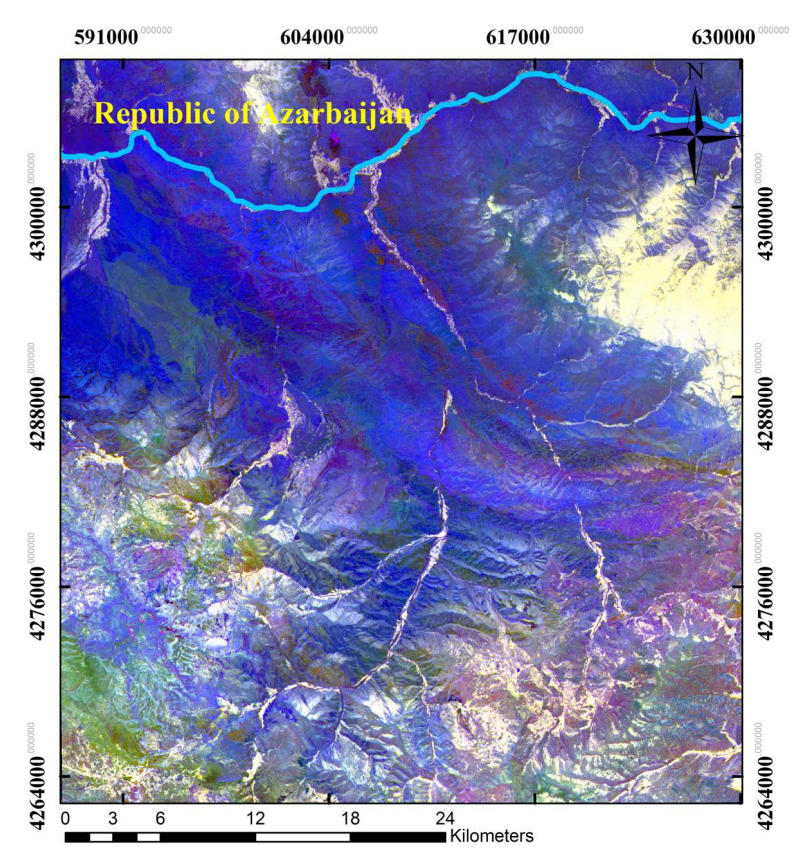

Figure 21. Color composite ratio of band ratios B3/B5, B3/B1, and B5/B7 in RGB respectively.

ASTER VNIR + SWIR + TIR data, and also ASAR data, C-Band imagery, improved the accuracy of analyzing geological structures, lineament identification. Band ratio and color composite were selected for detailed alteration minerals mapping. The two methods have high-level of similarity in the mapping results. As a result, 6 sites were mapped as the high-potential mineralized area (Figure 23).

Part A: the direction of lineaments in this part is N75 and altered rocks are matched with this trend of lineaments and Sharafabad-Hizejan Epithermal Gold mine has been occurred along of this lineaments and alteration zone. 


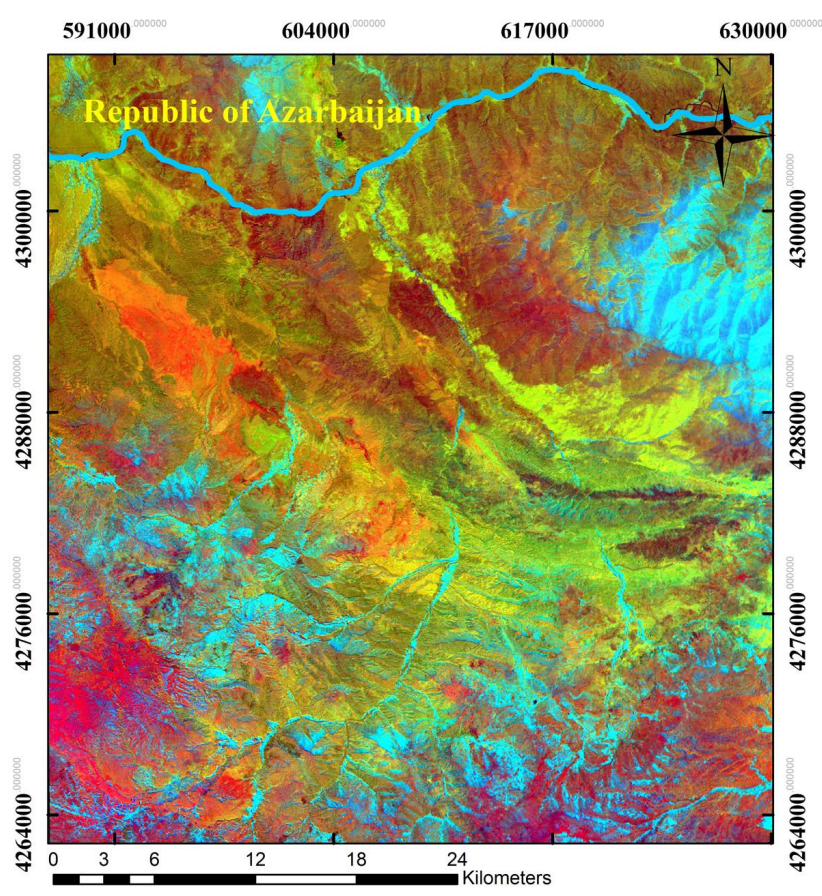

Figure 22. VNIR and SWIR color composite ratio images created by applying band ratio B2/B1, B4/B9, B3/B2 to red (R), green $(G)$, and blue (B) (R:G:B) that yellow color represents the presence of hydrothermal alteration.

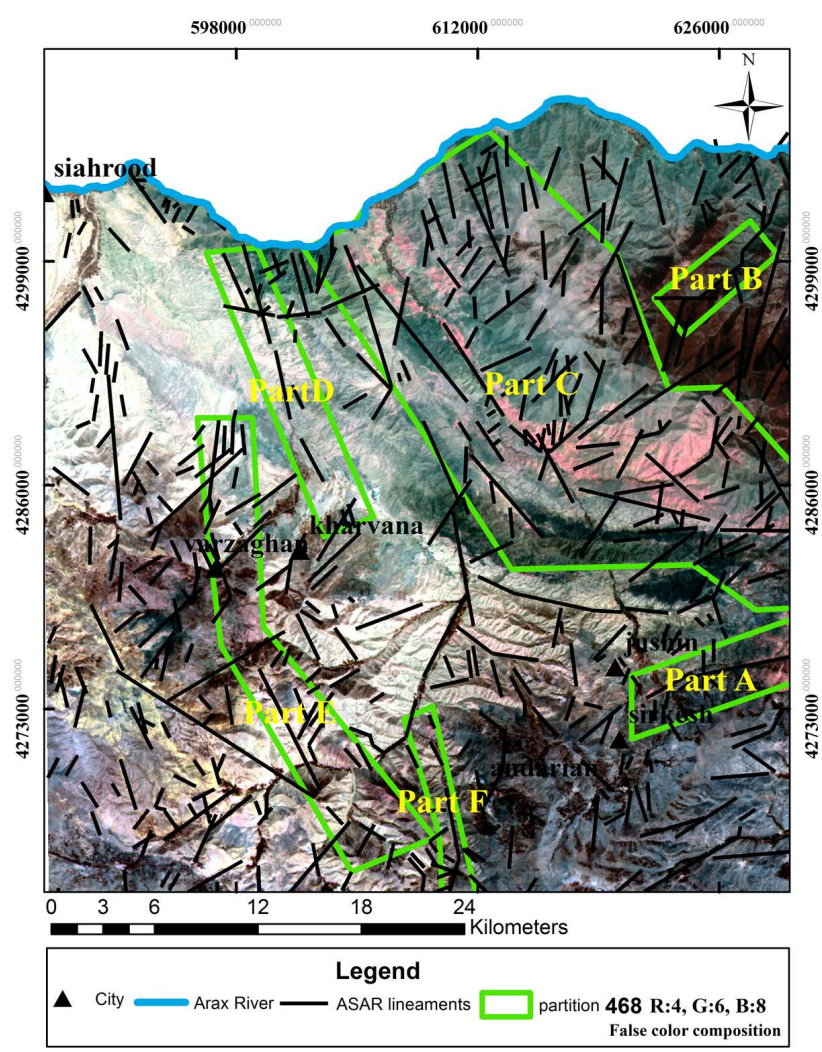

Figure 23. Lineaments and alteration zones map of Siyahrood area. 
Part B: lineaments direction in this part is N36 and Cu-Mo bearing rocks in altered rocks are matched each other.

Part C: the main trend of lineaments is N240 and mineralized zone is coincided with this direct and Cu bearing veins, $\mathrm{Cu}-\mathrm{Fe}$ mineralized zones, and $\mathrm{Fe}$ mineralized zones are occurred in this area (Aniq-Qarechilar $\mathrm{Cu}-$ Mo-Au mine, Avan and Astamal and northern Avan Fe-Cu mine).

Part D: the main trend of lineaments in this part is N251 and Fe Skarn type mineralization zone of Kamtalore body is situated along this lineaments.

Part E: the direction of lineaments in north part of this area is N-S and in southern part is N242 and As mineralization has been occurred in this part as Dastjerd mine in northern part and Atashkhosro mine.

Part F: dominant trend of lineaments is N262. In this trend Au epithermal and porphyry $\mathrm{Cu}-\mathrm{Au}$ mineralization have been occurred as Mive rood, and Asterqan mine.

\section{Conclusion}

This study presented an investigation into integration satellite Remote Sensing and ArcGIS techniques for detecting lineaments that might be related to faults and mineralization zones. At the first step, an RADAR (ASAR) single-band image has been processed for lineaments identification; at the second step, ASTER multi-spectral images have been applications mainly related to mapping rock types and identified alteration zones; and at the end step, relationship between lineaments and alteration zones has been investigated. Over lapping extracted lineaments (from ASAR imagery) and alteration zones (from ASTER data) show that the NW-SE, N-S, and NE-SW fractures represent potential zones for Au-Cu-Mo-As-Fe exploration. It is concluded that the proposed methods can be used as a powerful tool for ore deposit exploration; ASTER images can be employed for mineral characterization; and ASAR data can be employed for lineaments identification. In conclusion, we have shown that identification of hydrothermal alteration zones over wide area is possible and detailed information on alteration for the purposes of exploration of mineralized zones can be obtained using the proposed ASTER image creation methods.

\section{Acknowledgements}

This study was conducted as a part of Ph.D. degree granted by Islamic Azad University, North Tehran Branch.

\section{References}

[1] Arian, M. (2013) Physiographic-Tectonic Zoning of Iran’s Sedimentary Basins. Open Journal of Geology, 3, $169-177$. http://dx.doi.org/10.4236/ojg.2013.33020

[2] Qorashi, M. and Arian, M. (2011) Tectonics of Iran. Geologic Survey of Iran, Tehran, 336 p.

[3] Arian, M. (2011) Basement Tectonics and Geology of Iran. Asar Nafis Press, Qum, 300 p.

[4] Arian, M. (2011) A Preface on Salt Diapirism of Iran. Asar Nafis Press, Qum, 309 p.

[5] Arian, M. and Noroozpour, H. (2015) The Biggest Salt-Tongue Canopy of Central Iran. Open Journal of Geology, 5, 55-60. http://dx.doi.org/10.4236/ojg.2015.52005

[6] Asadian, F., Pourkermani, M. and Arian, M. (2007) Tectonic Geomorphology of Salt Structures in the GarmsarLasjerd Area. Geographical Research, 39, 75-84.

[7] Pourkermani, M. and Arian, M. (1997) Salt Domes of Central Iran. Journal of Humanities, 3, $29-41$.

[8] Arian, M. (2012) Salt Diapirism and Tectonics. 2nd Edition, Asar Nafis Press, Qum, 319 p.

[9] Arian, M. and Noroozpour, H. (2015) Tectonic Geomorphology of Iran’s Salt Structures. Open Journal of Geology, 5, 61-72. http://dx.doi.org/10.4236/ojg.2015.52006

[10] Asadian, F. and Arian, M. (2009) Identification of Diapiric Provinces of Central Iran through Geological and Geographical Analysis. International Journal of Agriculture Environment \& Biotechnology, 2, 3443-3451.

[11] Arian, M. (2012) Clustering of Diapiric Provinces in the Central Iran Basin. Carbonates and Evaporites, 27, 9-18. http://dx.doi.org/10.1007/s13146-011-0079-9

[12] Pourkermani, M. and Arian, M. (1998) Tectonic Geomorphology of Salt Domes in West of Zanjan Province, Iran. Geographical Research, 47, 44-53.

[13] Arian, M. and Feizi, F. (2010) The Significance of Faulting on the Surficial Spreading of Evaporitic Deposits in the Varamin-Semnan Area. Journal of Earth and Resources, 3, 1-20. 
[14] Feizi, F., Arian, M. and Arian, A. (2015) Mud Diapirism on the Makran, Iran: Case Study on the Napag Mud Volcano. Open Journal of Geology, 5, 300-308. http://dx.doi.org/10.4236/ojg.2015.55027

[15] Arian, M. and Sistanipour, A. (2015) Mud Diapirism on the Gorgan. North Iran Open Journal of Geology, 5, 442-450.

[16] Arian, M. and Khodabakhshnezhad, A. (2015) Sedimentary Environments Can Be Changed by Geotechnology (Case Study: A Morphotectonic Idea for Design of Extensive Artificial Bay on the Iranian Plateau). International Journal of Geosciences, 6, 487-496. http://dx.doi.org/10.4236/ijg.2015.65039

[17] Arian, M. (2011) Middle East Tectonics. Asar Nafis Press, Qum, 236 p.

[18] Arian, M. (2010) Applied Seismotectonics. Farazamin Press, Tehran, 304 p.

[19] Arian, M. and Maleki, R. (2008) Neotectonics. Farazamin Research Center, Tehran, 150.

[20] Pourkermani, M. and Arian, M. (1998) Seismicity of Iran. Shahid Beheshti University Press, Tehran, 212.

[21] Pourkermani, M. and Arian, M. (1997) Seismotectonics. DezAb Consulting Engineers Company Press, Tehran, 270.

[22] Arian, M. and Aram, Z. (2014) Relative Tectonic Activity Classification in the Kermanshah Area, Western Iran. Solid Earth, 5, 1277-1291. http://dx.doi.org/10.5194/se-5-1277-2014

[23] Mashal, M., PourKermani, M., Charchi, A., Almasian, M. and Arian, M. (2013) Pattern of Structural Geology Underground in Eastern of North Dezfol Embayment. Advances in Environmental Biology, 7, 260-268.

[24] Pazhoohan, M., Arian, M., Ghorashi, M. and Khosrotehrani, K. (2014) A Study of Drainage Pattern Responses to Active Tectonics in Tadvan Region, SW Iran. Geodynamics, 1, 36-41.

[25] Rahimi, N. and Arian, M. (2014) Tectonic Geomorphplogy of Kangavar-Sosangerd Region, West Iran. Advances in Environmental Biology, 8, 119-124.

[26] Arian, M. and Hashemi, A. (2008) Seismotectonic Zoning in the Zagros. Journal of Sciences, 18, 63-76.

[27] Arian, M., Ahmadnia, A., Qorashi, M. and Pourkermani, M. (2002) Structural Analysis of Mengharak Transcurrent Fault System in Zagros, Iran. Special GEO 2002 Conference Issue Geoarabia, 7, 209-210.

[28] Arian, M., Qorashi, M. Pourkermani, M. and Ahmadnia, A. (2003) Fractal Analysis of Mengharak Transcurrent Fault System in Zagros, Iran. Proceedings of the Fourth International Conference on Seismology and Earthquake Engineering, Tehran, 12-14 May 2003, 23.

[29] Baharvand, S., Pourkermani, M., Ajalloian, R., Arian, M. and Nouryazdan, A.R. (2010) Seymareh Landslide and Its Role in Environmental and Geomorphologic Changes of the Pole-Dokhtar Area. Journal of the Earth, 4, 13-24.

[30] Abdideh, M., Qorashi, M., Rangzan, K. and Arian, M. (2011) Assessment of Relative Active Tectonics Using Morphometric Analysis, Case Study of Dez River (Southwestern, Iran). Geosciences, 20, 33-46.

[31] Arian, M., Qorashi, M., Pourkermani, M. and Ahmadnia, A. (2006) The Structural Significance Kareh Bas Transcurrent Fault System in the Zagros Fold and Thrust Belt. Geosciences, 15, 126-133.

[32] Arian, M. and Noroozpour, H. (2015) Seismic Activity and Fractal Geometry of Kareh Bas Fault System in Zagros, South of Iran. Open Journal of Geology, 5, 291-299. http://dx.doi.org/10.4236/ojg.2015.55026

[33] Ehsani, J. and Arian, M. (2015) Quantitative Analysis of Relative Tectonic Activity in the Jarahi-Hendijan Basin Area, Zagros Iran. Geosciences Journal, 19, 1-15. http://dx.doi.org/10.1007/s12303-015-0016-3

[34] Omidali, M., Arian, M. and Sorbi, A. (2015) Neotectonics of Boroujerd Area, SW Iran by Index of Active Tectonics. Open Journal of Geology, 5, 309-324.

[35] Chegini, A., Sorbi, A. and Arian, M. (2015) Active Tectonics of Hamedan Area, SW Iran by Index of Active Tectonics. International Journal of Geology, 4, 108-118.

[36] Maleki, Z., Arian, M., Solgi, A. and Ganjavian, M.A. (2014) The Elements of Fold Style Analysis in the Khaftar Anticline, Zagros, Iran. Open Journal of Geology, 4, 79-92. http://dx.doi.org/10.4236/ojg.2014.43008

[37] Maleki, Z., Arian, M. and Solgi, A. (2014) Structural Style and Hydrocarbon Trap of Karbasi Anticline, in the Interior Fars Region, Zagros, Iran. Solid Earth Discussions, 6, 2143-2167. http://dx.doi.org/10.5194/sed-6-2143-2014

[38] Ehsani, J., Arian, M. and Ghorashi, M. (2015) Geomorphic Signatures of Active Tectonics in the Jarahi-Hendijan Drainage Basin in the South West Iran. Geosciences, 24, 211-218.

[39] Khodabakhshnezhad, A., Pourkermani, M., Arian, M., Matkan, A.A. and Charchi, A. (2015) Active Tectonics of Great Karounriver Basin. Geosciences, 24, 13-28.

[40] Maleki, Z., Arian, M., Solgi, A. and Ganjavian, M.A. (2015) Elements of Fold Style Analysis in the Karbasi Anticline, Interior Fars Region, Zagros. Geosciences, 24, 293-302.

[41] Baratpour, F., Arian, M. and Solgi, A. (2015) Geometric Analysis of Tukak and Kamarun Anticlines on Izeh Zone, Zagros. Geosciences, 24, 191-200.

[42] GholamhoseinFard, N., Sorbi, A. and Arian, M. (2015) Active Tectonics of Kangavar Area, West Iran. Open Journal 
of Geology, 5, 422-441.

[43] Maleki, Z., Arian, M. and Solgi, A. (2015) Folding Pattern in the Fars Province, Zagros Folded Belt: Case Study on the Karbasi and Khaftar Anticlines, Interior Fars, Iran. Solid Earth Discussions, 7, 2347-2379.

[44] Alladin, Y., Talebian, M., Arian, M. and Ahmadi, M.M. (2015) Geotechnical Investigation and Seismic Zonation of Alluvial Deposits in Western Tehran. Geosciences, 24, 333-342.

[45] Taherkhani, B., Nazari, H., Pourkermani, M. and Arian, M. (2015) Geometry and Recent Kinematics of the North Qazvin Fault: Morphotectonic Approach. Geosciences, 24, 29-38.

[46] Manuchehri, H., Arian, M., Ghorashi, M., Solgi, M. and Sorbi, A. (2015) Geomorphic Signatures of Active Tectonics in the Chalus Drainage Basin in the Alborz, Iran. Geosciences, 24, 273-280.

[47] Noroozpour, H., Arian, M. and Sorbi, A. (2015) Fault Movement Potentials in the Tehran-Semnan Region (North Iran). Open Journal of Geology, 5, 281-290.

[48] Arian, M., Maleki, Z. and Noroozpour, H. (2011) Cenozoic Diastrophism and Deformational Events in the East Central Alborz. Journal of Basic and Applied Scientific Research, 1, 2394-2400.

[49] Feizi, F., Arian, A. and Rahmani, R. (2007) Seismotectonic Zoning in the Eastern Part of the Central Alborz. Journal of Sciences, 17, 151-164. http://dx.doi.org/10.4236/ojg.2015.55025

[50] Khavari, R., Arian, M. and Ghorashi, M. (2009) Neotectonics of the South Central Alborz Drainage Basin, in NW Tehran, N Iran. Journal of Applied Sciences, 9, 4115-4126. http://dx.doi.org/10.3923/jas.2009.4115.4126

[51] Arian, M. and Bagha, N. (2012) Active Tectonics of Tehran Area, Iran. Journal of Basic and Applied Scientific Research, 2, 3805-3819.

[52] Bagha, N., Arian, M., Ghorashi, M., Pourkermani, M., El Hamdouni, R. and Solgi, A. (2014) Evaluation of Relative Tectonic Activity in the Tehran Basin, Central Alborz, Northern Iran. Geomorphology, 213, 66-87. http://dx.doi.org/10.1016/j.geomorph.2013.12.041

[53] Arian, M. and Feizi, F. (2005) Application of Geomorphic Indices to the Assessment of Relative Tectonic Activity Levels in the Alborz-Central Iran Border Zone. Journal of Sciences, 15, 378-403.

[54] Arian, M., Bagha, N., Khavari, R. and Noroozpour, H. (2012) Seismic Sources and Neo-Tectonics of Tehran Area (North Iran). Indian Journal of Science and Technology, 5, 2379-2383.

[55] Moghimi, H., Arian, M. and Sorbi, A. (2015) Fault Movement Potential of Marzanabad Area, North Alborz, Iran. Open Journal of Geology, 5, 126-135. http://dx.doi.org/10.4236/ojg.2015.53012

[56] Arian, M. and Pourkermani, M. (2004) Tectonic Elements of South Flank in the East-Central Alborz Mountain. Journal of Sciences, Teacher Training University, 4, 359-368.

[57] Arian, M. and Qorashi, M. (2006) The Movement Potential Evaluation of the Major Quaternary Faults in Alborz-Central Iran Border Zone, from the East of Tehran to the East of Semnan. Journal of Geosciences, Geological Survey of Iran, 15, 184-188.

[58] Poroohan, N., Pourkermani, M. and Arian, M. (2013) An Assessment of Relationship in F-Parameter and Paleostress Fields in Heterogeneous Lithologies: Roudbar Area (Northwest of Iran). Australian Journal of Basic \& Applied Sciences, 7, 933-942.

[59] Poroohan, N., Poukermani, M. and Arian, M. (2009) An Assessment on Correlations of Seismotectonic Parameters Preceding and Following Roudbar-Manjil Earthquake (Gilan, North of Iran). Australian Journal of Basic \& Applied Sciences, 3, 2643-2652.

[60] Farrokhnia, A.R., Pirasteh, S., Pourkermani, M. and Arian, M. (2011) Geo-Information Technology for Mass Wasting Hazard Zonation: Central-West Alborz-Iran. Disaster Advances, 4, 24-33.

[61] Khavari, R., Ghorashi, M. and Arian, M. (2009) Assessment of Relative Active Tectonics, South Central Alborz (North Iran). EGU General Assembly Conference Abstracts, 11, 1137.

[62] Sorbi, A., Arian, M. and Pourkermani, M. (2009) The Movement Potential Evaluation of the Major Quaternary Faults in Tehran Quadrangle. Journal of the Earth, 19, 176-182.

[63] Feizi, F. and Arian, M. (2006) The Classification of Thrust Fronts in the Alborz-Central Iran Border Zone from the East of Varamin to the East of Semnan. Journal of Sciences, 16, 75-87.

[64] Arian, M. and Feizi, F. (2005) Application of Geomorphic Indices to the Assessment of Relative Tectonic Activity Levels in the Alborz-Central Iran Border Zone. Journal of Science, 15, 378-403.

[65] Arian, M. and Pourkermani, M. (2004) Structural Significance of North Semnan and Attary Faults in Alborz-Central Iran Border Zone. Journal of Science, 14, 4551-4569.

[66] Arian, M. and Pourkermani, M. (2005) Cenozoic Diastrophism and Deformational Events in the Southern Flank of Central-East Alborz. Journal of Faculty Earth Sciences, 10, 43-51. 
[67] Arian, M., Pourkermani, M., Qorashi, M. and Ghasemi, M.R. (2003) North Semnan Fault System and Its Role on Basin Division. Proceedings of the 8th Symposium of Geological Society of Iran, Shahrood, 4-6 September 2003, 11-17.

[68] Pourkermani, M. and Arian, M. (2001) Structural Geomorphology of Northeastern Kurdistan. Journal of Humanities, 7, 37-48.

[69] Mardani, Z., Ghorashi, M. and Arian, M. (2011) Geomorphic Signatures of Active Tectonics in the Talaghanrud, Shahrudand Sefidrud Drainage Basins in Central Alborz, N Iran. Geosciences, 20, 159-166.

[70] Sorbi, A., Arian, M. and Pourkermani, M. (2011) The Application of Geomorphic Indices to the Assessment of Relative Tectonic Activity Levels in Tehran Quadrangle. Journal of the Earth, 6, 1-9.

[71] Khavari, R., Ghorashi, M., Arian, M. and Khosrotehrani, K. (2010) Geomorphic Signatures of Active Tectonics in the Karaj Drainage Basin in South Central Alborz, N Iran. Geosciences, 19, 67-74.

[72] Mousavi, E.J. and Arian, M. (2015) Tectonic Geomorphology of Atrak River, NE Iran. Open Journal of Geology, 5, 106-114. http://dx.doi.org/10.4236/ojg.2015.53010

[73] Nouri, R., Jafari, M.R., Arian, M., Feizi, F. and Afzal, P. (2013) Correlation between Cu Mineralization and Major Faults Using Multifractal Modelling in the Tarom Area (NW Iran). Geologica Carpathica, 64, 409-416. http://dx.doi.org/10.2478/geoca-2013-0028

[74] Nouri, R., Jafari, M.R., Arian, M., Feizi, F. and Afzal, P. (2013) Prospection for Copper Mineralization with Contribution of Remote Sensing, Geochemical and Mineralographical Data in Abhar 1:100,000 Sheet, NW Iran. Archives of Mining Sciences, 58, 1071-1084. http://dx.doi.org/10.2478/amsc-2013-0074

[75] Nouri, R., Afzal, P., Arian, M., Jafari, M. and Feizi, F. (2013) Reconnaissance of Copper and Gold Mineralization Using Analytical Hierarchy Process in the Rudbar 1:100,000 Map Sheet, Northwest Iran. Journal of Mining and Metallurgy, 49, 9-19.

[76] Farrokhnia, A.R., Pirasteh, S., Pradhan, B., Pourkermani, M. and Arian, M. (2011) A Recent Scenario of Mass Wasting and Its Impact on the Transportation in Alborz Mountains, Iran Using Geo-Information Technology. Arabian Journal of Geosciences, 4, 1337-1349. http://dx.doi.org/10.1007/s12517-010-0238-7

[77] Arian, M. and Nouri, R. (2015) Lineament Tectonics and Mineralization in Tarom Area, North Iran. Open Journal of Geology, 5, 115-124. http://dx.doi.org/10.4236/ojg.2015.53011

[78] Feizi, F. and Arian, M. (2011) The Role of Structural Controllers in Geneses of Copper Deposits in 1:50000 Map of Saiin Qaleh. Journal of Sciences, 21, 1-10.

[79] Arian, M., Qorashi, M. and Ahmadnia, A. (2003) Analysis of Behbahan Shear Zone. Iranian journal of Geology, 1, 14.

[80] Bahiraee, S., Arian, M., Qorashi, M. and Solgi, M. (2015) The Movement Potential Evaluation of the Mosha Fault (The West of Firoozkuh to the Shahrestanak). Geosciences, 24, 123-126.

[81] Bagha, N., Ghorashi, M., Arian, M., Pourkermani, M. and Solgi, A. (2015) Neotectonic Analysis of Mosha-North Tehran Fault Zone, Based on Morphotectonic Features, Central Alborz, Northern Iran. Geosciences, 24, 41-52.

[82] Mosavi, E. and Arian, M. (2015) Neotectonics of Kashaf Rud River, NE Iran by Modified Index of Active Tectonics (MIAT). International Journal of Geosciences, 6, 776-794. http://dx.doi.org/10.4236/ijg.2015.67063

[83] Nouri, R. and Arian, M. (2015) Structural Control on the Distribution of Hydrothermal Alteration Zones and Mineralization in Dastjerdeh Area Based on Remote Sensing Data, NW Iran. Bulletin of the Georgian National Academy of Sciences, 9, 79-86.

[84] Sistanipour, A. and Arian, M. (2015) Geometric Analysis of Davaran Fault System, Central Iran. Open Journal of Geology, 5, 458-469.

[85] Nazemi, M., Ghorashi, M., Ghassemi, M.R. and Arian, M. (2015) Morphotectonics Features of Alluvial Fans Associated with Active Tectonics (Shotori Mountains, East of Tabas-Central Iran). Geosciences, 24, 91-100.

[86] Alizadeh, H. and Arian, M. (2015) Rule of Structural Factors in Formation of Porphyry Copper Deposits in South Western Part of Kerman Area, Iran. Open Journal of Geology, 5, 489-498.

[87] Mosavi, E.J. and Arian, M. (2015) Neotectonics of Tabas Area, Central Iran by Index of Active Tectonics (IAT). Open Journal of Geology, 5, 209-223. http://dx.doi.org/10.4236/ojg.2015.54019

[88] Daryani, N.J., Arian, M. and Omran, N.R. (2015) Tectonics and Mineralization of Copper in the Ardestan-Kahang Area, Central Iran by Remote Sensing. Open Journal of Geology, 5, 188-196. http://dx.doi.org/10.4236/ojg.2015.54017

[89] Arian, M. and Pourkermani, M. (2001) Rivers Morphology and Active Tectonic (Reviewing the Current Status of Ghezel Ozon River in the Province of Zanjan). Proceedings of the 5th Conference of Geological Society of Iran, Tehran, 28-30 August 2001, 556.

[90] Eshghi, Z., Arian, M. and Pourkermani, M. (2012) Structural Investigation on the Lak Mining Area (Bueen Zahra) 
Based on Remote Sensing, Used for Its Mineralization. Journal of the Earth, 6, 145-155.

[91] Arian, M., Toudeshki, V.H. and Noroozpour, H. (2011) Active Tectonics of Qezel Ozan River Basin, NW Iran. Journal of Applied Environmental and Biological Sciences, 1, 291-295.

[92] Alizadeh, H., Arian, M., Lotfi, M., Ghorashi, M. and Ghorbani, M. (2015) Determination of Porphyry Copper Deposit Locations Using Photo Lineament Factor in Northern Parts of the Dehaj-Sardoiyeh Belt. Geosciences, 24, 247-252.

[93] Toudeshki, V.H., Pourkermani, M., Arian, M. and Khosrotehrani, K.H. (2011) Influence of Structures on the Ghezel Ozan River. Geosciences, 21, 55-60.

[94] Toudeshki, V.H. and Arian, M. (2011) Morphotectonic Analysis in the Ghezel Ozan River Basin, NW Iran. Journal of Geography and Geology, 3, 258-260.

[95] Arian, M. (2015) Seismotectonic-Geologic Hazards Zoning of Iran. Earth Sciences Research Journal, 19, 7-13. http://dx.doi.org/10.15446/esrj.v19n1.40664

[96] Arian, M., Pourkermani, M., Sistanipour, A. and Noroozpour, H. (2011) Kinematic Significance of Fold- and FaultRelated Fracture Systems in the Rafsanjan’s Northeast Highlands (Central Iran). Journal of Basic and Applied Scientific Research, 1, 3398-3406.

[97] Arian, M., Pourkermani, M., Sistanipour, A. and Noroozpour, H. (2011) Seismicity and Fault Segmentation of BafqBaghin Fault System (Central Iran). Journal of Applied Environmental and Biological Sciences, 1, 382-396.

[98] Mosavi, E.J., Arian, M., Ghorashi, M. and Nazemi, M. (2012) Measurments of Geomorphic Indices in Tabas Area. Journal of the Earth, 7, 213-225.

[99] Arian, M. (2010) Earthquake-Fault Hazard Investigations in the Kerman Quadrangle. Journal of Sciences, 19, $176-182$.

[100] Mehrpartou, M. (1997) Geological Map of Siahrood (1:100,000). Geological Survey of Iran.

[101] Mokhtari, M.A.A. (2009) Petrology, Geochemistry, and Petrogenesis of Qara-Dagh Batholith (East of Siahrood, Eastern Azerbeijan) and Associated Skarn Deposits with Considering on Mineralization. Unpublished PhD Thesis, Tarbiat Modares University, Tehran, 303 p. (In Persian with English Abstract)

[102] Rowan, L.C. and Lathram, E.H. (1980) Chapter 17: Mineral Exploration. In: Siegal, B.S. and Gillespie, A.R., Eds., Remote Sensing in Geology, John Wiley and Sons, New York, 553-605.

[103] Sabins, F.F. (1997) Remote Sensing: Principles and Interpretation. W. H. Freeman and Company, New York, 361.

[104] Koike, K., Nagano, S. and Ohmi, M. (1995) Lineament Analysis of Satellite Images Using a Segment Tracing Algorithm (STA). Computers and Geosciences, 21, 1091-1104. http://dx.doi.org/10.1016/0098-3004(95)00042-7

[105] Fujisada, H. (1995) Design and Performance of ASTER Instrument. Proceedings of the International Society for Optical Engineering, 2583, 16-25.

[106] Sillitoe, R.H. (2010) Porphyry Copper Systems. Economic Geology, 105, 3-41. http://dx.doi.org/10.2113/gsecongeo.105.1.3

[107] Drury, S.A., Ed. (2001) Image Interpretation in Geology. 3rd Edition, Nelson Thornes, Cheltenham, 304 p.

[108] Gad, S. and Kusky, T. (2007) ASTER Spectral Ratioing for Lithological Mapping in the Arabian-Nubian Shield, the Neoproterozoic Wadi Kid Area, Sinai, Egypt. Gondwana Research, 11, 326-335. http://dx.doi.org/10.1016/j.gr.2006.02.010

[109] Amer, R., Kusky, T. and Ghulam, A. (2010) Lithological Mapping in the Central Eastern Desert of Egypt Using ASTER Data. Journal of African Earth Sciences, 56, 75-82. http://dx.doi.org/10.1016/j.jafrearsci.2009.06.004

[110] Lyon, R.J.P. and Lee, K. (1970) Remote Sensing in Exploration for Mineral Deposits. Economic Geology, 65, 785-800. http://dx.doi.org/10.2113/gsecongeo.65.7.785

[111] Watson, K. (1975) Geological Applications of Thermal Infrared Images. Proceedings of the IEEE, 63, 128-137. http://dx.doi.org/10.1109/PROC.1975.9712

[112] Kahle, A.B. and Rowan, L.C. (1980) Evaluation of Multispectral Middle Infrared Aircraft Images for Lithologic Mapping in the East Tintic Mountains, Utah. Geology, 8, 234-239. http://dx.doi.org/10.1130/0091-7613(1980)8<234:EOMMIA>2.0.CO;2

[113] Abrams, M.J., Kahle, A.B., Palluconi, F.D. and Schieldge, J.P. (1984) Geologic Mapping Using Thermal Images. Remote Sensing of Environment, 16, 13-33. http://dx.doi.org/10.1016/0034-4257(84)90024-5

[114] Kahle, A.B. (1976) Thermal Inertia Imaging: A New Geologic Mapping Tool. Geophysical Research Letters, 3, 419421. http://dx.doi.org/10.1029/GL003i001p00026

[115] Kahle, A.B., Schieldge, J.P. and Alley, R.E. (1984) Sensitivity of Thermal Inertia Calculations to Variations in Environmental Factors. Remote Sensing of Environment, 16, 211-232. http://dx.doi.org/10.1016/0034-4257(84)90065-8

[116] Price, J.C. (1977) Thermal Inertia Mapping: A New View of the Earth. Journal of Geophysical Research, 82, 2582- 
2590. http://dx.doi.org/10.1029/JC082i018p02582

[117] Mars, J.C. and Rowan, L.C. (2006) Regional Mapping of Phyllic- and Argillic-Altered Rocks in the Zagros Magmatic Arc, Iran, Using Advanced Spaceborne Thermal Emission and Reflection Radiometer (ASTER) Data and Logical Operator Algorithms. Geosphere, 2, 161-186. http://dx.doi.org/10.1130/GES00044.1

[118] Rowan, L.C., Hook, S.J., Abrams, M.J. and Mars, J.C. (2003) Mapping Hydrothermally Altered Rocks at Cuprite, Nevada, Using the Advanced Spaceborne Thermal Emission and Reflection Radiometer (ASTER), a New Satellite-Imaging System. Economic Geology, 98, 1019-1027. http://dx.doi.org/10.2113/gsecongeo.98.5.1019

[119] Boloki, M. and Poormirzaee, M. (2010) Using ASTER Image Processing for Hydrothermal Alteration and Key Alteration Minerals Mapping. Journal of Latest Trends on Engineering Mechanics, Structures, Engineering Geology, 1, 7782. 